\title{
ANALISA SIKAP KERJA DOKTER GIGI YANG BERHUBUNGAN DENGAN KELUHAN NYERI PINGGANG DI RUMAH SAKIT SURABAYA
}

\author{
Edwindi Refresitaningrum ${ }^{1}$, Indriati Paskarini ${ }^{2}$ \\ ${ }^{1}$ Program Studi S1 Kesehatan Masyarakat, Fakultas Kesehatan Masyarakat, Universitas Airlangga \\ ${ }^{2}$ Departemen Keselamatan dan Kesehatan Kerja, Fakultas Kesehatan Masyarakat, Universitas \\ Airlangga \\ Email: nien.dianto@gmail.com
}

\begin{abstract}
Dentist is a part of the hospital which most likely to suffer low back pain injury because ergonomic working position. This research was to analyze dentist's working position at hospital $X$ Surabaya. This was a descriptive research, depend on the collection of the data this was an observasional research with cross sectional method. The subject of this research were seven dentist at hospital X Surabaya. Variable in this research were age, gender, working period, working time, smoking, exercising and working position. Method to collect the data were questionnaire and interview. Data analyzed with descriptive method and shown with cross tabulation. This research showed that five of seven respondents were under 30 years old (71\%) and almost all of them were woman. Most respondent's had working period less than 5 years who works 8 hours each day. And almost of them didn't do an exercise. Most of dentist's working position categorized in very high category with scoring +7 and low back pain injury include in middle category. Conclusion of this research showed there was a strong relation between dentist's working position with low back pain injury. To minimalized low back pain, hospital should make a good time management for the dentist. Also gived them knowledge about the best working position. The dentist's should exercise and had a good rest.
\end{abstract}

Keyword: working position, low back pain, dentist

\begin{abstract}
ABSTRAK
Dokter gigi merupakan tenaga medis di Rumah Sakit yang cukup berpotensi terkena keluhan nyeri pinggang, karena sikap kerja yang tidak ergonomis. Tujuan penelitian ini adalah menganalisis sikap kerja dokter gigi yang berhubungan dengan keluhan nyeri pinggang di Rumah Sakit X Surabaya. Penelitian ini merupakan observasional dengan rancang bangun cross sectional. Subjek penelitian adalah seluruh dokter gigi di RS X Surabaya sebanyak 7 dokter gigi. Variabel yang diteliti adalah usia, jenis kelamin, masa kerja, lama kerja, kebiasaan merokok, kebiasaan olahraga, sikap kerja dan keluhan nyeri pinggang. Pengambilan data dengan cara kuesioner dan observasi. Data dianalisis secara deskriptifdengan hasil tabulasi silang. Hasil penelitian menunjukkan bahwa 5 dari 7 responden berusia $<30$ tahun $(71 \%)$ dan sebagian besar berjenis kelamin perempuan. Masa kerja responden sebagian besar kurang dari 5 tahun dengan lama kerja sebagian besar responden lebih dari 8 jam per hari. Sebagian besar responden tidak rutin berolahraga. Sikap kerja dokter gigi sebagian besar termasuk dalam kategori sangat tinggi dengan skoring 7+ yang artinya diperlukan adanya investigasi dan perbaikan secepat mungkin sedangkan keluhan nyeri pinggang termasuk kategori sedang.Hasil penelitian diketahui bahwa hubungan antara sikap kerja dokter gigi dengan keluhan nyeri pinggang tersebut memiliki hubungan yang cukup kuat. Rumah Sakit disarankan untuk mengatur waktu dan lama istirahat dokter gigi dan memberikan pelatihan kepada dokter gigi tentang bagaimana sikap kerja yang baik sehingga dapat mengurangi resiko keluhan nyeri pinggang. Dokter gigi disarankan untuk rajin berolahraga serta istirahat yang cukup.
\end{abstract}

Kata kunci: sikap kerja, keluhan nyeri pinggang, dokter gigi 
Edwindi, et al. Analisa Sikap Kerja Dokter Gigi Yang Berhubungan Dengan Keluhan Nyeri Pinggang di Rumah Sakit Surabaya

\section{PENDAHULUAN}

Undang-Undang Nomor 13 Tahun 2003 Tentang Ketenagakerjaan, Pasal 86 ayat 2 yang menyatakan bahwa di setiap tempat kerja wajib menyelenggarakan Upaya Kesehatan dan Keselamatan Kerja untuk melindungi keselamatan dan kesehatan pekerja guna mewujudkan produktivitas kerja yang optimal (Presiden Republik Indonesia, 2003). Kesehatan merupakan faktor yang sangat penting bagi produktivitas serta peningkatan kinerja tenaga kerja selaku sumber daya manusia. Kondisi kesehatan yang baik berpotensi untuk meraih produktivitas kerja yang baik, dimana pekerjaan yang menuntut produktivitas kerja tinggi hanya dapat dilakukan oleh tenaga kerja dengan kondisi kesehatan prima. Berbeda jika dalam keadaan sakit atau adanya gangguan kesehatan dapat menyebabkan tenaga kerja kurang produktif dalam pekerjaannya (Suma'mur, 2009).

Implikasi ergonomi yaitu berupaya untuk menyeserasikan pekerjaan dengan tenaga kerja, sehingga akan tercipta kenyamanan kerja. Kelelahan yang cepat muncul karena adanya pekerjaan yang monoton, adanya rasa sakit sewaktu bekerja, fisik dan mental yang berat serta berlangsung lama, akan dapat menyebabkan masalah pada mental psikologi, dimana dengan aplikasi ergonomi masalah kelelahan dapat ditekan sekecil mungkin. Ergonomi membantu menghindarkan beban tambahan bagi pekerja, sehingga segala kemampuan, kebolehan dan batasan seorang pekerja hanya ditujukan pada pelaksanaan pekerjaan pokok yang menjadi tugasnya. Apabila ergonomi tidak dipenuhi, akan timbul rasa tidak nyaman atau sakit pada bagian tubuh tertentu. Pada pekerja dengan sikap kerja yang salah sering menimbulkan keluhan nyeri di bagian pinggang.

Di Amerika Serikat diperkirakan lebih dari $15 \%$ orang dewasa mengalami keluhan nyeri pinggang atau nyeri yang bertahan hampir dua minggu. Nyeri pinggang merupakan suatu gejala sakit yang terjadi pada bagian pinggang dan merupakan work related musculoskeletaldisorders. Nyeri pinggang telah teridentifikasi oleh Pan American Health Organization antara tiga masalah kesehatan pekerjaan yang dikenal oleh WHO. Prevalensi sebesar 37\% daripada keluhan nyeri pinggang disebabkan oleh pekerjaan, dengan perbandingan lebih banyak terjadi pada lakilaki daripada perempuan. Sedangkan penelitian
JPH RECODE Maret 2018; 1 (2) : 109-119 http://e-journal.unair.ac.id/JPHRECODE
Community Oriented Program for Controle of Rheumatic Disease (COPORD) Indonesia menunjukan bahwa prevalensi nyeri terjadi pada penduduk yang berusia diatas 65 tahun dimana prevalensi nyeri pinggang yang terjadi pada laki-laki sekitar 18,2 \% dan 13,6\% terjadi pada wanita. National Safety Council juga melaporkan bahwa sakit akibat kerja yang paling tinggi frekuensi kejadiannya adalah nyeri pada pinggang, yaitu 22\% dari 1.700 .000 kasus (Tarwaka et al., 2004).

Menurut ILO tahun 2007, setiap tahun terjadi kematian sebanyak 1,1 juta yang disebabkan oleh penyakit atau disebabkan oleh pekerjaan. Data tersebut juga menyebutkan bahwa terdapat 300.000 kematian yang terjadi dari 250 juta kecelakaan dan sisanya adalah kematian karena penyakit akibat kerja. Selain penyakit akibat kerja yang menyebabkan kematian, juga terdapat masalah kesehatan lain yang perlumendapatkan perhatian antara lain ketulian, gangguan musculoskeletal, gangguan reproduksi, penyakit jiwa, sistem syaraf dan sebagainya (Umami, 2014).

Berdasarkan penelitian Samara et al., (2005) yang menyatakan bahwa masalah nyeri pinggang diakibatkan karena duduk yang cukup lama sekitar 90-300 menit dan dalam keadaan statis dan tidak memiliki kesempatan untuk berelaksasi. Keluhan nyeri pinggang terjadi karena masalah duduk dalam bekerja atau yang aktivitasnya lebih banyak dilakukan dengan duduk.

Nyeri pinggang akibat kerja yang terjadi apabila postur tubuh saat bekerja tidak ergonomis. Contohnya membungkuk, jongkok atau duduk di lantai dan memaksa posisi tubuh yang tidak alami (Tarwaka et al., 2004).

Gangguan nyeri pinggang merupakan faktor risiko pada profesi dokter gigi. Pada beberapa penelitian sebelumnya diketahui bahwa prevalensi nyeri pinggang yang terjadi pada dokter gigi sekitar $25-85 \%$ dari 1.645 dokter gigi yang berusia diatas 45 tahun. Keluhan nyeri pinggang dapat dipengaruhi beberapa faktor, diantaranya faktor intrinsik yaitu karakteristik individu (umur, jenis kelamin, masa kerja, lama kerja, kebiasaan olahraga, status gizi, kebiasaan merokok, dll.) dan sikap kerja. Selain itu juga dipengaruhi oleh faktor ekstrinsik yaitu beban pekerjaan dan kondisi lingkungan kerja (Andayasari, 2012).

Seperti hasil penelitian yang dilakukan oleh Wijaya et al., (2011) diketahui bahwa 
Edwindi, et al. Analisa Sikap Kerja Dokter Gigi Yang Berhubungan Dengan Keluhan Nyeri Pinggang di Rumah Sakit Surabaya

gangguan muskuloskeletal banyak terjadi pada dokter gigi. Hasil skrinning didapat sekitar 80\% dari 70 mahasiswa dengan menggunakan instrumen Body Discomfort Map dan Brief Survey di FKG UI bahwa gangguan muskuloskeletal terutama terjadi pada anggota tubuh bagian leher, bahu, lengan bawah, tangan dan punggung.

Dokter gigi merupakan pelayanan paripurna dalam bidang kesehatan gigi dan mulut yang bertujuan untuk meningkatkan status kesehatan gigi dan mulut. Dalam penyelenggara kesehatan di Rumah Sakit, dokter gigi setiap hari kontak langsung dengan pasien dalam waktu yang cukup lama, dimana tugasnya meliputi pelayanan darurat (cedera, reposisi dislokasi sendi rahang), pelayanan pencegahan (tindakan penanaganan dini, tindakan perlindungan khusus), pelayanan medik dasar (perawatan gigi, ekstraksi gigi, pengobatan abses, dll.) dan pelayanan medik khusus (konservasi, orthodonti, bedah mulut, dll.).

Rumah Sakit X Surabaya merupakan salah satu Rumah Sakit Umum Swasta unggulan di Surabaya, yang berdiri sejak tahun 1927. Berbagai jenis pelayanan baik rawat jalan, rawat inap maupun penunjang ada di Rumah Sakit X serta didukung dengan tenaga medis yang profesional dan berpengalaman dibidangnya.

Pelayanan rawat jalan di Rumah Sakit X Surabaya yang dapat beresiko terjadi gangguan atau cedera nyeri pinggang salah satunya adalah klinik gigi umum, klinik gigi spesialis konservasi dan klinik gigi spesialis orthodonti. Penyebab dokter gigi mengalami keluhan nyeri pinggang dikarenakan dokter gigi hanya memperhatikan kenyamanan bagi pasien yang dirawatnya, tetapi kurang memperhatikan kenyamanan bagi diri sendiri saat merawat pasiennya. Kebanyakan gangguan nyeri pinggang terjadi karena dokter gigi tanpa sadar berada pada posisi tubuh atau sikap kerja tidak alamiah saat merawat pasien misalnya saat melakukan preparasi gigi atau mencabut gigi, sikap kerja dokter gigi membungkuk ke arah pasien, bergerak secara mendadak, memutar tubuh dari satu sisi ke sisi yang lain. Seluruh gerakan tersebut dilakukan berkali-kali dalam jangka waktu yang panjang.

Tujuan dari penelitian ini adalah menganalisa sikap kerja dokter gigi yang berhubungan dengan keluhan nyeri pinggang di Rumah Sakit X Surabaya.
JPH RECODE Maret 2018; 1 (2) : 109-119 http://e-journal.unair.ac.id/JPHRECODE

\section{METODE}

Berdasarkan cara pengambilan data, penelitian ini merupakan jenis penelitian observasional dengan rancang bangun penelitian cross sectional, karena peneliti hanya melakukan pengamatan tanpa member adanya perlakuan serta pengambilan data dengan kuesioner dilakukan sekaligus pada suatu saat itu juga.

Penelitian dilakukan untuk menganalisa suatu keadaan secara obyektif yaitu sikap kerja (postur tubuh) dengan keluhan nyeri pinggang pada dokter gigi di Rumah Sakit X Surabaya.

Subyek penelitian ini adalah seluruh dokter gigi di Rumah Sakit X Surabaya sebanyak 7 dokter gigi. Pengambilan data di lapangan dilakukan bulan November sampai dengan Desember 2015.

Variabel dari penelitian ini adalah adalah usia, jenis kelamin, masa kerja, lama kerja, kebiasaan merokok, kebiasaan olahraga, sikap kerja dan keluhan nyeri pinggang. Pengambilan data dengan cara kuesioner dan observasi. Data yang diperoleh dianalisis secara deskriptif dan disajikan dalam bentuk tabulasi silang.

\section{HASIL}

\section{Karakteristik Responden}

Berdasarkan hasil penelitian yang telah dilakukan terhadap dokter gigi di klinik gigi Rumah Sakit X Surabaya diperoleh data untuk faktor karakteristik responden sebagai berikut :

\section{Usia Responden}

Usia responden dibagi menjadi 3 kelompok, yaitu kelompok umur $<30$ tahun, 30-40 tahun dan >40 tahun. Berdasarkan hasil kuesioner yang telah dilakukan kepada dokter gigi di klinik gigi Rumah Sakit X Surabaya, didapatkan hasil bahwa dari 7 dokter gigi di Rumah Sakit X Surabaya sebagian besar berusia <30 tahun sebanyak 5 responden (71\%) dan yang berusia $>40$ tahun sebanyak 2 responden $(29 \%)$.

\section{Jenis Kelamin Responden}

Jenis kelamin responden dibagi menjadi 2 kelompok, yaitu kelompok perempuan dan laki-laki. Berdasarkan hasil kuesioner yang telah dilakukan kepada dokter gigi di klinik gigi Rumah Sakit X Surabaya, didapatkan hasil bahwa dari 7 dokter gigi di Rumah Sakit X Surabaya sebagian besar berjenis kelamin perempuan sebanyak 5 responden $(71 \%)$ dan 
Edwindi, et al. Analisa Sikap Kerja Dokter Gigi Yang Berhubungan Dengan Keluhan Nyeri Pinggang di Rumah Sakit Surabaya

yang berjenis kelamin laki-laki sebanyak 2 responden $(29 \%)$.

\section{Lama Kerja Responden}

Lama kerja responden dibagi menjadi 3 kategori, yaitu kategori 1-4 jam/hari, 5-8 jam/hari dan $>8$ jam/hari. Berdasarkan hasil kuesioner yang telah dilakukan kepada dokter gigi di klinik gigi Rumah Sakit X Surabaya, didapatkan hasil bahwa lama kerja dari 7 dokter gigi di Rumah Sakit X Surabaya sebagian besar lama kerjanya adalah 5-8 jam/hari sebanyak 3 responden $(43 \%)$, dan hanya 4 responden $(57 \%)$ lainnya lama kerja > $8 \mathrm{jam} / \mathrm{hari}$.

\section{Masa Kerja Responden}

Masa kerja responden dikategorikan dalam 3 kelompok, diantaranya masa kerja $<5$ tahun, masa kerja 5-10 tahun dan masa kerja $>10$ tahun. Berdasarkan hasil kuesioner yang telah dilakukan kepada dokter gigi di klinik gigi Rumah Sakit X Surabaya, didapatkan hasil bahwa masa kerja dari 7 dokter gigi di Rumah Sakit X Surabaya sebagian besar masa kerjanya $\leq 5$ tahun sebanyak 5 responden (71\%) dan hanya 2 responden (29\%) memiliki masa kerja $\geq 10$ tahun.

\section{Kebiasaan Merokok Responden}

Kebiasaan merokok dibagi menjadi 4 (empat) kategori yaitu tidak merokok, perokok ringan, perokok sedang dan perokok berat. Berdasarkan hasil kuesioner yang telah dilakukan kepada dokter gigi di klinik gigi Rumah Sakit X Surabaya didapatkan hasil bahwa semua dokter gigi di klinik gigi Rumah Sakit X Surabaya sebanyak 7 responden (100\%) tidak memiliki kebiasaan merokok.

\section{Kebiasaan Olahraga Responden}

Kebiasaan olahraga dibagi menjadi 3 (tiga) kategori, yaitu kategori iya melakukan olahraga dengan rutin, kategori tidak rutin atau kadang-kadang melakukan olahraga, dan tidak melakukan olahraga. Berdasarkan hasil kuesioner yang telah dilakukan kepada dokter gigi di klinik gigi Rumah Sakit X Surabaya didapatkan hasil bahwa dokter gigi di klinik gigi Rumah Sakit X Surabaya menunjukkan bahwa sebagian besar tidak memiliki kebiasaan berolahraga yaitu sebanyak 3 responden $(43 \%)$, sedangkan sisanya responden melakukan olahraga tetapi tidak rutin atau kadang-kadang yaitu sebanyak 4
JPH RECODE Maret 2018; 1 (2) : 109-119 http://e-journal.unair.ac.id/JPHRECODE responden (57\%). Untuk jenis, frekuensi dan lama olahraga distribusinya adalah sebagai berikut :

Jenis Olahraga: jenis olahraga dokter gigi di klinik gigi Rumah Sakit X Surabaya yang didapat dari hasil kuesioner diketahui bahwa jenis olahraga yang dilakukan dokter gigi di Rumah Sakit X Surabaya adalah jogging sebanyak 2 responden $(50 \%)$, renang sebanyak 1 responden $(25 \%)$, dan bersepeda sebanyak 1 responden (25\%).

Frekuensi Olahraga: frekuensi olahraga dokter gigi di klinik gigi Rumah Sakit $\mathrm{X}$ Surabaya yang didapat dari hasil kuesioner diketahui bahwa frekuensi kebiasaan olahraga perminggu yang dilakukan oleh dokter gigi adalah $1 \mathrm{x}$ sebanyak 3 responden $(75 \%)$ dan yang melakukan olahraga $2 \mathrm{x}$ perminggu sebanyak 1 responden $(25 \%)$.

Lama Olahraga: lama olahraga dokter gigi di Rumah Sakit X Surabaya yang didapat dari hasil kuesioner diketahui bahwa lama olahraga yang dilakukan dokter gigi adalah $\leq$ 15 menit sebanyak 1 responden (25\%), sedangkan lama olahraga15-30 menit sebanyak 1 responden $(25 \%)$ dan yang lama olahraga $\geq$ 30 menit sebanyak 2 responden $(50 \%)$.

\section{Identifikasi Sikap Kerja Pada Dokter Gigi di Klinik Gigi Rumah Sakit X Surabaya Berdasarkan Metode Rapid Upper Limb Assesment (RULA)}

Identifikasi sikap kerja yang dapat menimbulkan keluhan nyeri pinggang yang dilakukan pada tujuh responden yaitu dokter gigi yang bekerja di klinik gigi Rumah Sakit X Surabaya dimana pekerjaannya meliputi pemeriksaan, perawatan gigi, penambalan gigi, pembersihan karang gigi maupun yang lainnya yang sesuai dengan kompetensinya. Identifikasi sikap kerja dilakukan dengan menggunakan metode RULA.Metode RULA merupakan metode yang digunakan untuk menilai sikap kerja yang mengalami keluhan muskuloskeletal atau keluhan nyeri pinggang.Pembagian segmen tubuh juga dilakukan dalam metode ini.

Nilai RULA didapat dari hasil observasi dengan menilai sudut flexi atau ektensi yang dibentuk oleh lengan atas, lengan bawah, pergelangan tangan, putaran pergelangan tangan, leher, kaki, badan dan penambahan tekanan atau otot.Sikap kerja yang dilakukan penilaian adalah sikap kerja yang paling sering dilakukan oleh responden. 
Hasil akhir dengan menggunakan metode RULA adalah untuk menentukan tingkat risiko cedera dengan menetapkan tingkat tindakan korektif yang diperlukan serta melakukan intervensi untuk segera dilakukan perbaikan.

Berdasarkan hasil identifikasi didapat skor akhir bahwa sebagian besar responden termasuk dalam kategori sangat tinggi dengan skor 7+ yang berarti sikap kerja dokter gigi perlu dilakukan penyelidikan dan perbaikan secepat mungkin. Penyelidikan dan perbaikan sikap kerja pada dokter gigi yang memiliki risiko sangat tinggi, diperlukan secepatnya agar dapat memperkecil dan mencegah terjadinya keluhan nyeri pinggang yang lebih tinggi.Perbaikan sikap kerja dengan perubahan posisi kerja dengan berdiri dan duduk, sikap kerja yang tidak membungkuk, menekuk dan memuntir serta perbaikan stasiun kerja seperti bentuk kursi dokter gigi yang ergonomik.

Metode RULA merupakan informasi penting dari setiap kemungkinan terjadinya resiko ergonomi yang berhubungan dengan sikap tubuh selama proses kerja. Standar kinerja berdasarkan pada skor akhir dapat dilihat pada tabel 1 .

Tabel 1. Standar Kinerja Berdasarkan Skor Akhir RULA

\begin{tabular}{ccl}
\hline Skor Akhir & Level & \multicolumn{1}{c}{ Tindakan } \\
\hline $1-2$ & 1 & Tidak ada masalah dengan postur tubuh selama kerja \\
\hline $3-4$ & 2 & $\begin{array}{l}\text { Diperlukan investigasi lebih lanjut, mungkin diperlukan adanya } \\
\text { perubahan untuk erbaikan sikap kerja }\end{array}$ \\
\hline $5-6$ & 3 & \begin{tabular}{l} 
Diperlukan adanya investigasi dan perbaikan segera \\
\hline $7+$
\end{tabular} \\
\hline
\end{tabular}

Sumber: Tarwaka (2010)

Hasil penilaian sikap kerja dokter gigi dapat disimpulkan bahwa sebagian besar sikap kerja pada dokter gigi termasuk dalam kategori sangat tinggi sebanyak 4 responden $(57 \%)$ dan 3 responden (43\%) memiliki sikap kerja kategori tinggi, maka diperlukan adanya investigasi dan perbaikan secepat mungkin agar mengurangi terjadinya keluhan nyeri pinggang.

\section{Identifikasi Keluhan Nyeri Pinggang dengan Metode Nordic Body Map.}

Identifikasi keluhan nyeri pinggang dalam penelitian ini menggunakan metode Nordic Body Map (NBM), yaitu dengan menggunakan lembar kerja berupa peta tubuh dan mudah dipahami karena dapat diketahui bagian-bagian otot yang mengalami keluhan dengan tingkat keluhan mulai dari rasa tidak sakit (skor 1), agak sakit (skor 2), sakit (skor 3) dan sangat sakit (skor 4). Kemudian dikonversikan dalam bentuk skor dan dikategorikan menjadi empat yaitu keluhan rendah, sedang, tinggi dan sangat tinggi, maka akandapat diketahui tingkat risiko keluhan setiap responden.
Metode penilaian Nordic Body Mapsangat subyektif sehingga keberhasilan metode ini besar tergantung dari kondisi dan situasi yang dialami responden pada saat dilakukannya penilaian. Metode NBM yang menggunakan lembar kerja berupa peta tubuh meliputi 28 cara pembagian otot rangka pada kedua sisi tubuh kanan dan kiri. Hal tersebut diukur dari bagian atas tubuh, pertama otot leher sampai bagian paling bawah adalah otot pada kaki. Kuesioner Nordic Body Map pada metode ini dugunakan agar dapat diketahui bagian otot mana saja yang mengalami nyeri atau keluhan lain

Keluhan nyeri pinggang hampir pasti dapat dikatakan bahwa resiko penyakit akibat kerja.Munculnya keluhan sebagian besar setelah bekerja selama 5 tahun lebih atau bisa saja kurang dari 5 tahun. Keluhan nyeri pinggang bisa karena sikap tidak alamiah dalam melakukan pekerjaannya. Penilaian keluhan nyeri pinggang dengan Berikut merupakan klasifikasi dari penilaian tingkat keluhan muskuloskeletal menggunakan Nordic Body Map. Skor NBM dapat dilihat pada tabel 2. 
Tabel 2. Skor Nordic Body Map

\begin{tabular}{cccl}
\hline Tingkat Aksi & $\begin{array}{c}\text { Total Skor } \\
\text { Individu }\end{array}$ & $\begin{array}{c}\text { Tingkat } \\
\text { Resiko }\end{array}$ & \multicolumn{2}{c}{ Tindakan Perbaikan } & \\
\hline 1 & $28-49$ & Rendah & Belum diperlukan adanya tindakan perbaikan \\
\hline 2 & $50-70$ & Sedang & Mungkin diperlukan tindakan dikemudian hari. \\
\hline 3 & $71-91$ & Tinggi & $\begin{array}{l}\text { Diperlukan tindakan segera. } \\
\text { Diperlukan tindakan menyeluruh sesegera } \\
\text { mungkin. }\end{array}$ \\
\hline
\end{tabular}

Sumber : Tarwaka (2010)

Tabel 3. Distribusi Sikap Kerja Dokter Gigi di Klinik Gigi Rumah Sakit X Surabaya Tahun 2015

\begin{tabular}{|c|c|c|c|c|c|c|}
\hline \multirow{3}{*}{ Sikap Kerja } & \multicolumn{4}{|c|}{$\begin{array}{c}\text { Penilaian Resiko Keluhan } \\
\text { Nyeri Pinggang/Otot Skeletal }\end{array}$} & \multirow{2}{*}{\multicolumn{2}{|c|}{ Total }} \\
\hline & \multicolumn{2}{|c|}{ Rendah } & \multicolumn{2}{|c|}{ Sedang } & & \\
\hline & $\mathbf{n}$ & $\%$ & $\mathbf{n}$ & $\%$ & $\mathbf{n}$ & $\%$ \\
\hline Tinggi, Skor RULA 5-6 & 2 & 66,67 & 1 & 33,33 & 3 & 100 \\
\hline Sangat Tinggi, Skor RULA 7+ & 1 & 25 & 3 & 75 & 4 & 100 \\
\hline Total & 3 & & 4 & & 7 & 100 \\
\hline
\end{tabular}

Hubungan Sikap Kerja dengan Keluhan Nyeri Pinggang pada Dokter Gigi di Klinik Gigi Rumah Sakit X Surabaya

Analisis tabulasi silang antara sikap kerja dengan keluhan nyeri pinggang menunjukkan ada atau tidaknya hubungan antara sikap kerja dengan keluhan nyeri pinggang. Skor sikap kerja menggunakan metode RULA dibedakan menjadi empat kategori, yaitu rendah, sedang, tinggi dan sangat tinggi. Keluhan nyeri pinggang dibedakan menjadi rendah, sedang, tinggi, dan sangat tinggi.Hasil distribusi antara sikap kerja dokter gigi dengan keluhan nyeri pinggang dapat dilihat pada tabel 3 .

Dari hasil diatas dapat disimpulkan bahwa dokter gigi yang memiliki sikap kerja dalam kategori sangat tinggi sebanyak 3 responden $(75 \%)$ mengalami keluhan nyeri pinggang sedang. Berdasarkan hasil tabulasi silang bahwa terdapat hubungan yang cukup kuat antara sikap kerja dokter gigi di RS X dengan tingkat risiko keluhan nyeri pinggang.

\section{PEMBAHASAN}

Usia

Dari hasil penelitian didapatkan bahwa sebagian besar dokter gigi berusia kurang dari 30 tahun yaitu sebanyak 5 dokter gigi atau sebesar $71 \%$ dan 2 dokter gigi (29\%) berusia lebih dari 40 tahun.

Rentang usia seseorang memiliki kapasitas fisik dan kekuatan otot maksimal, karena keluhan nyeri pinggang pada umumnya mulai menyerang pada usia 25-65 tahun.
Menurut Tarwaka (2010) menyatakan bahwa pada umumnya keluhan nyeri pinggang mulai menyerang antara usia 25-65 tahun. Keluhan pertama pada umumnya dirasakan pada usia 35 tahun dan tingkat keluhan akan terus meningkat sejalan dengan bertambahnya usia. Hal ini terjadi karena pada umur setengah baya, kekuatan dan ketahanan otot mulai menurun sehingga risiko terjadinya keluhan otot meningkat. Keluhan pertama biasanya dirasakan pada usia antara 20-29 tahun dan keluhan akan terus meningkat sejalan bertambahnya usia. Hal ini terjadi karena pada usia tersebut, kekuatan dan ketahanan otot mulai menurun sehingga risiko terjadinya keluhan otot meningkat.

Kelompok usia tersebut menunjukkan bahwa responden berada pada usia produktif. Berdasarkan hasil penelitian dan teori diatas, usia responden sebagian besar berusia kurang dari 30 tahun, sehingga mempunyai risiko keluhan nyeri pinggang yang kecil karena responden berada di usia yang produktif dan memiliki kekuatan otot yang maksimal. Sebab menurut Tarwaka (2010) usia mempunyai hubungan yang sangat erat dengan keluhan system muskuloskeletal, terutama pada otot leher dan bahu.

\section{Jenis Kelamin}

Dari hasil penelitian yang didapat bahwa sebagian besar responden besar berjenis kelamin perempuan yaitu sebanyak 5 responden (71\%) dan 2 responden (29\%) berjenis kelamin laki-laki. 
Edwindi, et al. Analisa Sikap Kerja Dokter Gigi Yang Berhubungan Dengan Keluhan Nyeri Pinggang di Rumah Sakit Surabaya

Beberapa hasil penelitian secara signifikan menunjukkan bahwa jenis kelamin sangat mempengaruhi tingkat risiko keluhan otot.Hal ini terjadi karena secara fisiologis, kemampuan otot wanita memang lebih rendah daripada pria. Menurut Tarwaka (2010) otototot perempuan memiliki ukuran yang lebih kecil dan memiliki kekuatan 1:3 atau 60\% dari pada otot laki-laki, terutama pada otot lengan, punggung dan kaki, sehingga daya tahan otot laki-laki lebih tinggi dibandingkan dengan perempuan. Menerut Nusdwinuringtyas (2007) yang dikutip oleh Fathoni .H (2009) bahwa laki-laki dan perempuan memiliki resiko yang sama terhadap keluhan nyeri pinggang sampai dengan usia 60 tahun, namun kenyataannya jenis kelamin dapat mempengaruhi munculnya keluhan nyeri pinggang sebab perempuan cenderung lebih sering mengalami keluhan nyeri pinggang saat siklus menstruasi, selain itu proses menoupause juga dapat menyebabkan kepadatan tulang berkurang akibat penurunan hormone esterogen sehingga memungkinkan lebih terjadi keluhan nyeri pinggang.

Berdasarkan hasil penelitian yang dibandingkan dengan teori diatas, maka yang berpotensi mempunyai risiko keluhan otot/nyeri pinggang yaitu responden berjenis kelamin perempuan karena hasil yang didapat sebagian besar responden berjenis kelamin perempuan.

\section{Lama Kerja}

Berdasarkan hasil penelitian, didapatkan bahwa 4 responden (57\%) melakukan pekerjaannya lebih dari 8 jam sehari. Hari kerja sendiri dimulai dari senin sampai dengan sabtu yang artinya pekerja memiliki 6 hari kerja. Sesuai dengan perhitungan lama kerja dalam sehari dikalikan dengan hari kerja dalam seminggu maka didapatkan lama kerja adalah lebih dari 50 jam dalam seminggu.

Umumnya, lama seseorang bekerja dalam sehari adalah 6-8 jam. Sisanya yaitu 1618 jam merupakan waktu untuk kehidupan bersama keluarga dan masyarakat, istirahat, tidur, dan lain-lain. Selama seminggu biasanya seseorang dapat bekerja dengan baik dalam waktu 40-50 jam (Suma'mur, 2009). Berbeda pada penelitian ini daya yang didapatkan adalah sebagian besar responden bekerja dengan jangka $>8$ jam dalam sehari. Disamping itu, produktifitas seseorang mulai menurun sesudah 4 jam bekerja, sedangkan
JPH RECODE Maret 2018; 1 (2) : 109-119 http://e-journal.unair.ac.id/JPHRECODE

responden bekerja dalam waktu lebih dari 8 jam sehari. Oleh karena itu wakttu istirahat selama setengah jam setelah bekerja sebanyak 4 jam kerja secara terus menerus sangat memiliki arti penting dalam diri seseorang.

\section{Masa Kerja}

Menurut Guo dalam Tarwaka (2010) masa kerja merupakan faktor yang berkaitan dengan berapa lama seseorang bekerja di suatu perusahaan.Terkait hal tadi, MSDs sebenarnya membutuhkan waktu lama untuk berkembang dan bermanifetasi dan merupakan sebuah penyakit kronis. Maka, semakin lama waktu bekerja atau semakin lama pula seseorang terpajan faktor risiko MSDs sama dengan besar risiko untuk mengalaminya.

Lama masa kerja sangat mempengaruhi ketrampilan dalam menjalankan pekerjaan. Semakin terampil seseorang melakukan pekerjaannya maka semakin efisien, sehingga beban kerja semakin kecil. Namun semakin lama bekerja, semakin tua usia tenaga kerja, semakin menurun juga kapasitas kerjanya (Suma'mur, 2009).

Gangguan keluhan nyeri pinggang muncul setelah mengalami masa kerja 3 sampai 5 tahun. Dalam penelitian ini didapatkan hasil bahwa sebagian besar dokter gigi memiliki masa kerja kurang dari 5 tahun sebesar 5 dokter gigi (71\%) sedangkan 2 dokter gigi (29\%) memiliki masa kerja lebih dari 10 tahun.

Berdasarkan hasil penelitian yang telah dibandingkan dengan Goa dalam Tarwaka (2010) dan beberpa ahli yang lainnya, maka pekerja yang sebagian besar bekerja $<5$ tahun seharusnya memiliki risiko kecil mengalami keluhan muskuloskeletal, tetapi hasil penelitian keluhan muskuloskeletal menggunakan lembar penilaian Nordic Body Map didapatkan bahwa mayoritas pekerja (dokter gigi) mengalami keluhan muskuloskeletal dengan tingkat keluhan sedang.

\section{Kebiasaan Merokok}

Hasil penelitian diketahui bahwa responden atau dokter gigi semuanya tidak memiliki kebiasaan merokok.

Pengaruh kebiasaan merokok terhadap risiko keluhan nyeri pinggang masih diperdebatkan para ahli. Menurut Boshuizen, et.al. (1993) dalam Tarwaka et al (2004) dikutip oleh Jannah (2014) menemukan hubungan yang signifikan antara kebiasaan 
Edwindi, et al. Analisa Sikap Kerja Dokter Gigi Yang Berhubungan Dengan Keluhan Nyeri Pinggang di Rumah Sakit Surabaya

merokok dengan keluhan nyeri pinggang, khususnya untuk pekerjaan yang memerlukan pengerahan otot. Kebiasaan merokok sebenarnya terkait erat dengan kondisi kesegaran tubuh seseorang. Kebiasaan merokok akan dapat menurunkan kapasitas paru-paru, sehingga kemampuan untuk mengonsumsi oksigen menurun dan sebagai akibatnya, tingkat kesegaran tubuh juga menurun.

Seseorang apabila harus melakukan tugas yang menuntut pengerahan tenaga maka akan mempercepat terjadinya keluhan karena kandungan oksigen dalam darah, pembakaran karbohidrat akan terhambat, terjadi penumpukan asam laktat dan akhirnya timbul rasa nyeri otot.

\section{Kebiasaan Olahraga}

Hasil penelitian untuk kebiasaan olahraga didapatkan bahwa yang memiliki kebiasaan olahraga meskipun jarang/kadangkadang sebanyak 4 responden atau dokter gigi $(57 \%)$ dan 3 responden lainnya tidak memiliki kebiasaan olahraga.

Aktifitas olahraga yang cukup dan teratur akan meningkatkan kemampuan kerja fisik (daya tahan otot) sehingga tidak mudah lelah dan memiliki ketahanan yang stabil serta meningkatkan kesegaran jasmani. Keluhan moskuletal bergantung pada tingkat kesegaran jasmani. Semakin rendah yingkat kesegaran jasamani maka akan semakin tinggi risiko terjadi keluhan muskuloskeletal dan begitu juga sebaliknya.

Berolahraga dapat meningkatkan temperatur, meningkatkan metabolisme dan tingginya kadar oksigen darah. Sehingga lama kelamaan otot tubuh akan menjadi kuat dan menambah daya tahan serta menghindari kelelahan otot. Olahraga juga dapat memberikan struktur tulang yang kuat dan stabil serta mencegah terjadinya cidera.

Menurut Tarwaka (2010) bahwa komponen kemampuan kerja fisik dan kesegaran jasmani seseorang ditentukan oleh kekuatan otot, ketahanan otot dan ketahanan kardiovaskuler. Melalui aktivitas olahraga yang cukup maka kekuatan otot, ketahanan otot dan ketahanan kardiovasculer dapat dicapai. Daya tahan otot pada prinsipnya dapat dilatih sejak dini sampai usia 20 tahun. Daya tahan otot mencapai kemampuan maksimum pada usia 25-30 tahun.
JPH RECODE Maret 2018; 1 (2) : 109-119 http://e-journal.unair.ac.id/JPHRECODE
Berdasarkan hasil penelitian yang dibandingkan dengan pendapat beberapa ahli, menyatakan bahwa 4 dari 7 responden/dokter gigi memiliki kebiasaan olahraga, yang berarti semakin meningkat kesegaran jasmani dan juga kekuatan dan ketahanan otot sehingga pekerja seharusnya memiliki risiko kecil mengalami keluhan nyeri pinggang, tetapi hasil penilaian muskuloskeletal menggunakan lembar penilaian Nordic Body Map didapatkan bahwa mayoritas pekerja (dokter gigi) mengalami keluhan muskuloskeletal dengan tingkat keluhan sedang.

\section{Sikap Kerja}

Analisa sikap kerja diperoleh dengan menggunakan metode RULA yaitu metode menilai postur, gaya dan gerakan suatu aktivitas kerja yang berkaitan dengan tubuh bagian atas (upper limb), metode ini mentransfer hasil analisis dalam bentuk skoring. Skor final yang diperoleh akan digunakan sebagai pertimbangan untuk memberikan saran perbaikan secara tepat. Factor risiko yang dinilai dengan menggunakan metode ini meliputi jumlah gerakan, kerja statis, gaya dan postur kerja yang ditentukan oleh perlengkapan.

Langkah dalam melakukan metode RULA menurut Tarwaka (2010) yaitu dimulai dengan mengobservasi aktivitas pekerjaannya. Dari observasi tersebut, dipilih pekerjaan dan postur tubuh yang paling signifikan. Pada saat memilih postur tubuh saat bekerja perlu mempertimbangkan aspek durasi atau beberapa postur kerja yang mengalami penggunaan otot dalam keadaan statis untuk waktu lebih dari 1 menit. Terdapat beberapa factor yang dapat menyebabkan keluhan musculoskeletal (keluhan nyeri pinggang) antara lain peregangan otot yang berlebihan, aktivitas berulang dan sikap kerja tidak alamiah (Peter Vi) dalam (Tarwaka, 2010).

Sikap kerja yang dilakukan responden (dokter gigi) cenderung dilakukan dengan tidak ergonomis yaitu posisi tubuh bergerak menjauhi posisi alamiah seperti punggung yang terlalu membungkuk, leher yang terlalu menunduk, posisi badan memuntir, pergelangan tangan yang menekuk dan lainnya. Sikap kerja yang tidak alamiah atau tidak ergonomis ini pada umumnya karena karakteristik tuntutan tugas, alat kerja dan stasiun kerja tidak sesuai dengan kemampuan dan keterbatasan pekerja (Manuaba, 2000). 
Berdasarkan hasil penelitian yang didapatkan bahwa sikap kerja responden sebagian besar memiliki 2 kategori yaitu kategori sangat tinggi dan kategori tinggi, sehingga diperlukan adanya penyelidikan dan perbaikan segera mungkin.

\section{Keluhan Nyeri Pinggang}

Berdasarkan hasil penelitian dapat diketahui bahwa 4 responden $(57 \%)$ memiliki keluhan nyeri pinggang kategori sedang dan 3 responden (43\%) termasuk kategori rendah. Keluhan nyeri pinggang adalah keluhan rasa nyeri yang berada didaerah pinggang atau otot rangka yang bersifat kronis yang dirasakan oleh seseorang beberapa lama setelah melakukan aktivitas dimulai dari keluhan sangat ringan hingga sangat sakit.

Identifikasi keluhan nyeri pinggang dalam penelitian ini menggunakan Nordic Body Map (NBM), yaitu dengan menggunakan lembar kerja berupa peta tubuh dan mudah dipahami karena dapat diketahui bagian-bagian otot yang mengalami keluhan dengan tingkat keluhan mulai dari rasa tidak sakit (skor 1), agak sakit (skor 2), sakit (skor 3) dan sangat sakit (skor 4). Kemudian dikonversikan dalam bentuk skor dan dikategorikan menjadi empat yaitu keluhan rendah, sedang, tinggi dan sangat tinggi, maka akandapat diketahui tingkat risiko keluhan setiap responden.

Metode penilaian Nordic Body Map sangat subyektif sehingga keberhasilan metode ini sangat tergantung dari kondisi dan situasi yang dialami responden pada saat dilakukannya penilaian. Dalam metode NBM yang menggunakan lembar kerja berupa peta tubuh meliputi 28 cara pembagian otot rangka pada kedua sisi tubuh kanan dan kiri. Dimulai dari bagian atas tubuh yaitu otot leher sampai dengan bagian paling bawah yaitu otot pada kaki. Melalui kuesioner Nordic Body Map maka akan dapat diketahui bagian otot mana saja yang mengalami keluhan atau nyeri.

Postur tubuh saat bekerja yang tidak ergonomis menjadi salah satu penyebab munculnya keluhan muskuloskeletal. Sebagian besar pekerja mengeluhkan adanya rasa nyeri pada bagian leher, punggung, pinggang, lengan bawah, pergelangan tangan, dan kaki. Kemudian otot skeletal pinggang yang dirasakan responden diakibatkan aktivitas responden yang posisi tubuh dengan sikap kerja yang tidak ergonomis yaitu dengan lengan atas dan bawah menjauhi tubuh, pergelangan tangan dan leher baik menekuk maupun memuntir, punggung terlalu membungkuk, menekuk kesamping dan memuntir.

Keluhan nyeri pinggang hampir pasti dapat dikatakan bahwa resiko penyakit akibat kerja. Munculnya keluhan sebagian besar setelah bekerja selama 5 tahun lebih atau bisa saja kurang dari 5 tahun.Keluhan nyeri pinggang bisa karena sikap tidak alamiah dalam melakukan pekerjaannya.

\section{Hubungan Sikap Kerja dengan Keluhan Nyeri Pinggang pada Dokter Gigi di Klinik Gigi Rumah Sakit X Surabaya}

Beberapa penelitian menyebutkan bahwa faktor yang paling berperan terhadap terjadinya keluhan nyeri pinggang adalah posisi kerja, seperti yang telah dilakukan oleh Wijaya et al (2011), pada dokter gigi didapatkan faktor yang paling berpengaruh terhadap keluhan nyeri pinggang adalah posisi kerja. Pada penelitian ini, yang dilakukan juga terhadap dokter gigi dimana yang akan diidentifikasi hubungan antara sikap kerja dengan keluhan nyeri pinggang. Sikap kerja yang menjadi variabel dalam penelitian ini adalah posisi lengan atas, posisi lengan bawah, posisi pergelangan tangan, posisi leher, posisi badan, dan posisi kaki.

Terdapat beberapa faktor yang dapat menyebabkan terjadinya keluhan nyeri pinggang. Beberapa faktor yang dimaksud oleh Peter Vi adalah peregangan otot yang berlebihan, aktivitas berulang, dan sikap kerja yang tidak alamiah. Faktor peregangan otot yang berlebihan, aktivitas berulang, dan sikap kerja yang tidak alamiah diukur dengan menggunakan metode RULA (Peter Vi) dalam (Tarwaka, 2010).

Sikap kerja yang tidak alamiah atau tidak ergonomis merupakan salah satu faktor yang dapat menimbulkan keluhan nyeri pinggan. Sikap kerja yang tidak alamiah adalah sikap kerja yang menyebabkan posisi pada bagian-bagian tubuh bergerak menjauhi posisi alamiah, misalnya pergerakan tangan terangkat menjauhi badan, punggung terlalu membungkuk, posisi leher terlalu menekuk dan sebagainya. Semakin jauh posisi bagian tubuh dari pusat gravitasi tubuh, maka semakin tinggi pula risiko terjadinya keluhan otot skeletal. Dalam metode RULA, sikap kerja yang tidak alamiah terlihat dari hasil akhir perhitungan. 
Edwindi, et al. Analisa Sikap Kerja Dokter Gigi Yang Berhubungan Dengan Keluhan Nyeri Pinggang di Rumah Sakit Surabaya

Faktor lainnya adalah peregangan otot yang berlebihan biasanya dikeluhkan oleh pekerja dengan aktivitas kerja yang menuntut penggunaan otot dan pengerahan tenaga selama melakukan pekerjaan seperti mencabut gigi, menambal gigi, merawat gigi dengan perawatan khusus dan lain sebagainya. Sikap tubuh pada saat bekerja dalam keadaan statis untuk waktu lebih dari 1 menit.Keluhan otot terjadi karena otot menerima tekanan akibat beban kerja secara terus menerus tanpa memperoleh kesempatan untuk relaksasi.

Berdasarkan hasil perhitungan sikap kerja menggunakan metode RULA, didapatkan hasil bahwa skor RULA dari aktivitas pekerjaan dokter gigi berada pada tingkat risiko sangat tinggi dan risiko tinggi mengalami kejadian muskuloskeletal.

Keluhan nyeri pinggang terjadi karena sikap kerja yang dilakukan tidak alamiah atau tidak ergonomis. Identifikasi keluhan nyeri pinggang pada responden dilakukan menggunakan metode Nordic Body Map (NBM). Hasil identifikasi keluhan nyeri pinggang menunjukkan bahwa responden mengalami keluhan nyeri pinggang dengan kategori sedang.

Berdasarkan hasil tabulasi silang antara sikap kerja dokter gigi dengan keluhan nyeri pinggang yang mempunyai hubungan yang cukup kuat dimana sesuai dengan teori Peter Vi dalam Tarwaka (2010) yang menjelaskan bahwa salah satu faktor yang mempengaruhi keluhan nyeri pinggang adalah sikap kerja yang tidak alamiah dan tidak ergonomis dalam pekerjaan.

Menurut Andayasari (2012) mengatakan bahwa prevalensi gangguan musculoskeletal bervariasi ditiap negara. Hal ini dikarenakan kurangnya memahami penyebab dari gangguan yang dialaminya, paling tidak tindakan apa yang harus dilakukan terhadap gangguan tersebut. Biasanya gangguan ini dianggap biasa atau wajar saja sehubungan dengan pekerjaan dan profesi mereka. Untuk itu dokter gigi perlu untuk mengetahui berbagai risiko terjadinya gangguan nyeri pinggang sehingga mereka dapat secara efektif mencegah timbulnya gejala keluhan, dan mereka juga harus memahami berbagai peralatan ergonomis, cara kerja yang baik dan gaya hidup. Ketiga hal ini merupakan kunci dalam mencegah timbulnya gangguan nyeri pinggang terkait dengan profesi dokter gigi.
JPH RECODE Maret 2018; 1 (2) : 109-119 http://e-journal.unair.ac.id/JPHRECODE

\section{KESIMPULAN}

Sebagian besar responden berusia kurang dari 30 tahun dan berjenis kelamin perempuan. Masa kerja responden sebagian besar kurang dari 5 tahun dengan lama kerja lebih dari 8 jam per hari. Responden sebagian besar tidak rutin berolahraga dan dalam satu minggu hanya satu kali dengan waktu olahraga sekitar lebih dari 30 menit.

Sikap kerja dokter gigi sebagian besar termasuk dalam kategori sangat tinggi dengan skoring +7 dalam metode RULA.

Dokter gigi sebagian besar mengalami keluhan nyeri pinggang dengan tingkat keluhan sedang. Keluhan otot skeletal yang banyak dikeluhkan dokter gigi seperti bagian pinggang, punggung, leher, pergelangan tangan.

Berdasarkan hasil penelitian menunjukkan bahwa ada hubungan antara sikap kerja dokter gigi dengan keluhan nyeri pinggang yang termasuk dalam tingkat hubungan yang cukup kuat.

\section{SARAN}

Rumah Sakit disarankan untuk mengatur waktu dan lama istirahat dokter gigi dan memberikan pelatihan kepada dokter gigi tentang bagaimana sikap kerja yang baik sehingga dapat mengurangi resiko keluhan nyeri pinggang. Dokter gigi disarankan untuk rajin berolahraga serta istirahat yang cukup.

\section{DAFTAR PUSTAKA}

Andayasari, L. 2012. Gangguan Musculoskeletal Pada Praktik Dokter Gigi dan Upaya Pencegahannya. Journal Media Litbang Kesehatan, 22(2), pp. 7077.

Manuaba, A. 2000. Ergonomi, Kesehatan dan Keselamatan Kerja. Surakarta: Uniba Press.

Presiden Republik Indonesia. 2003. UndangUndang No.13 Tahun 2003 tentang Ketenagakerjaan.

Samara, D. et al. 2005. Duduk Statis sebagai Faktor Risiko Terjadinya Nyeri Punggung Bawah pada Pekerja Perempuan. Universitas Medicina, 24(2), pp. 73-79.

Suma'mur, P. K. 2009. Higiene perusahaan dan kesehatan kerja (Hiperkes). Jakarta: Sagung Seto.

Tarwaka, Bakri, S.H.A, dan Sudiajeng, L. 
2004. Ergonomi untuk Keselamatan, Kesehatan Kerja dan Produktivitas. [ebook] Surakarta: UNIBA Press.

Tarwaka. 2010. Ergonomi Industri Surakarta: Harapan Press.

Umami, D. 2014. Hubungan antara Karakteristik Responden dan Sikap Kerja Duduk dengan Keluhan Nyeri Punggung Bawah (Low Back Pain) Pada Pekerja Batik Tulis. Pustaka Kesehatan.

Wijaya, A. T., Darwita, R. R. dan Bahar, A. 2011. The Relation between Risk Factors and Musculoskeletal Impairment in Dental Students: a Preliminary Study. Journal of Dentistry Indonesia, 18(2), pp. 33-3. doi: 10.14693/jdi.v18i2.61. 